\title{
MATH LESSON STRATEGY BASED ON SERVICE AND COUNSELING SERVICES PRINCIPLES
}

\author{
Sutirna \\ University of Singaperbangsa Karawang \\ Corresponding e-mail: sutirna@,satff.unsika.ac.id
}

\begin{abstract}
There are some benefits of learning mathematics, namely (1) Learning math can solve a problem, (2) Learning math can help to trade, (3) Learning math can be the basic foundation of science, (4) Learning math can make us more thorough, careful and not careless, (5) Learning math can sharpen the way of thinking, and (6) Learning math can train patience. But during this mathematics learning, the students' achievement are still not optimal and their perceptions toward mathematics tend to negative such as math is scary, troublesome, boring, and difficult.

One of the factors is the lack of teaching strategies applied by math teachers during the learning process, especially with the role they have to guide as subject teachers. The math teacher said that the guiding task is not the task of math teacher but the teacher of BK in school. This is evident from the results of the research through questionnaires that most mathematics teachers ignore the role of mentors in implementing their teaching strategies and the false perception that guiding is not the task of subject teachers. It is wrong perception because teacher is not only to teach but also to be an educator and mentor.

Therefore it should immediately provide a discourse in implementing teaching strategies based on the guidance and counselling principles for teachers of mathematics in order to create the atmosphere of PAIKEM so it is expected that the quality of mathematics learning outcomes change the students' negative perceptions to positive perceptions in learning mathematics.

The conclusion of this research is that the Strategy of Teaching and Learning Mathematics is very important to be patterned through the use of guidance and counselling service principles from the preparation, implementation and evaluation phase. The preparation phase with harmonious, happy, and warm situation will greatly affect the process of implementation of learning that PAIKEM (active, innovative, creative, effective and fun learning) will produce qualified students. Sunaryo et al (2008) states that quality education is if the three areas are implemented synergistically including the field of administration, academic and student guidance.
\end{abstract}

Keywords: Strategy, Teaching, Learning and Principles of Guidance and Counselling Services

\section{A. INTRODUCTION}

The focus and subject for the principle of teaching is teacher. NCTM (National Council of Teachers Mathematics (in Walle, 2011: 3) states that teachers' duty in teaching is to encourage their students to ask questions, solve problems and discuss ideas, strategies, and completion of their students. In addition, it is said that effective mathematics teaching requires an understanding of what students know and need to learn, advocate and support them to learn it well.

Furthermore, the principle of learning that becomes the subject or focus is the student. The National Council of Teachers Mathematics (in Walle, 2011: 3) states that in learning mathematics students must understand what they are learning. In addition, it is said that students must learn math with understanding, actively build new knowledge from experience and actual knowledge.
By observing the principles of teaching and learning, there are two different focuses: teaching that focuses on teachers and learning that focuses on students. The teacher has to concern more on how the teaching tasks can create the students that have competence in preparation to live life and their future. Students with experience of learning process should always improve his knowledge.

But the reality that happen in the field today shows that the result of teaching and learning mathematics still has not given optimal results. As an illustration of the results of interviews with some junior high school students turns out that the subjects of mathematics are a scary subject, making uncomfortable, and always a problem for both students and parents when their sons and daughters get homework math. This phenomenon is a failure of mathematics teachers in implementing teaching and learning mathematics. The 
problem of mathematics teachers still tend to have a paradigm "Teacher Center", "King of Class" and lack of understanding of guiding principles and counseling.

Based on the above description, the Mathematics Teacher requires a precise and accurate teaching strategy and learning strategy adjusted to the circumstances in which the teacher is assigned. Understanding the principles of guidance and counseling services for teachers of mathematics is something that must be known and understood because in the guidance and counseling service principles, there are an athmosphere on who the teacher and students are, so that the wrong paradigm will be a new leap and also eliminate negative perceptions of students about Mathematics subjects.

Many strategies in mathematics teaching are often used by mathematics teachers such as inquiry strategy, problem solving, expository, discovery, deductive, inductive, expository, heuristic, team teaching, classical, small group, individual, face to face and through media. Of all the strategies aimed at mathematics can be understood by students and liked, but the reality that happens in the field still remains a negative phenomenon for some students toward mathematics.

It needs to be informed that based on personal experience when becoming a math teacher in junior high school in 1986 until 2007, it was indeed that the phenomenon of mathematics learning results was very poor, because there were only 3 to 5 students out of 40 students, or between $7.5 \%$ - $12.5 \%$, whose learning outcomes were satisfied. This fact still persists even though the strategy of teaching and learning of mathematics has been increasingly evolving according to the development of science and technology.

Furthermore, the experience of teaching mathematics at vocational high school (STM, now SMK) in 2002 to 2007 shows that the result of mathematics learning was just not satisfactory, even though it had used humanistic teaching and learning strategies.

If we look at the benefits of mathematics with the fact that the students' perceptions of mathematics and mathematics learning outcomes that are so poor, then this should be a very basic improvement in teaching and learning of mathematics very soon. Let us consider the benefits of studying mathematics thoroughly, namely (1) Learning math can solve a problem, (2) Learning math can help to trade, (3) Learning math can be the basic foundation of science, (4) Learning math can make us more thorough, careful and not careless, (5) Learning math can sharpen the way of thinking, and (6) Learning math can train patience.

Thus the teaching and learning strategies that have been used by teachers of mathematics have not given a significant impact either for the results of learning mathematics and students' negative perceptions toward mathematics. It seems that guidance and counseling principles should be the foundation for applying mathematical teaching and learning strategies, but math teachers still tend to be confused that guidance and counselling is a job for counselling teacher and it is not math teacher's job.

\section{B. LITERATURE STUDY}

Teaching and learning strategy is the activity of teachers in teaching and learning process that can provide facilities to students in order to achieve predetermined teaching objectives. Another definition says that the teaching-learning strategy consists of all components of teaching material (teaching package) and products that will be used to help students to achieve their goals.

According to Bloom, teaching objectives include three learning domains, namely cognitive (ability or knowledge), affective (attitude), and psychomotor (skills). Cognitive objectives include six aspects: recognition, understanding, application of analysis, synthesis and evaluation. The purpose of teaching affective learning areas consist of 5 levels: acceptance of attitudes or synthesis, responding, assessing attitudes, organizing attitudes and internalizing attitudes. The purpose of psychomotor learning consists of 5 levels: perception of stimuli, readiness, physical acting, directional response, mechanical response and conscious response.

The purpose of teaching mathematics is to prepare students to be able to deal with changes of situation and mindset in their life and the world that are always growing, and to prepare students to use mathematics and mathematical mindset in everyday life and in learning various science. Therefore, to achieve the purpose of teaching mathematics, it is needed to understand the guidance and counseling service principles in implementing the strategy of teaching and learning mathematics.

Moch. Djawad Dahlan, Rochman Kartawijaya, Sunaryo, Sutirna et al $(2008,2011,2013)$ state that the guidance and counseling service principles are as follows:

1. Guidance is a process of helping individuals to help themselves in solving the problems they face.

2. Guidance should be focused on guiding individual.

3. Guidance is directed at individuals and each individual has its own characteristics.

4. Problems that cannot be resolved by the coaching team within the institute environment should be handed over to the expert or authorized institution to resolve it.

5. Guidance begins with the identification of needs perceived by the individual to be guided.

6. Guidance should be flexible according to the needs of individuals and communities.

7. A coaching program within a particular educational institution should be in line with the educational program at the institution concerned.

8. The implementation of guidance programs should be managed by people with expertise in the field of guidance, may work together and use relevant resources that are inside or outside educational institutions.

9. Guidance programs should be implemented in the evaluation to find out the results and implementation of the program. 
Furthermore, how to apply the principle in mathematics teaching strategy can be considered in the following table 1:

Table 1

Activity Strategy of Teaching Math based on Guidance and Counselling Service Principles

\begin{tabular}{|c|c|c|}
\hline No & $\begin{array}{ll}\text { BK } & \text { Service } \\
\text { Principle } & \end{array}$ & $\begin{array}{c}\text { Teaching Strategy } \\
\text { Activities }\end{array}$ \\
\hline 1 & $\begin{array}{l}\text { Guidance is an } \\
\text { individual helping } \\
\text { process so that they } \\
\text { can help } \\
\text { themselves in } \\
\text { solving the } \\
\text { problems they face }\end{array}$ & $\begin{array}{l}\text { Mathematics teachers } \\
\text { are obliged to assist } \\
\text { students in solving } \\
\text { the problems of } \\
\text { learning mathematics } \\
\text { without complaints } \\
\text { with the principle that } \\
\text { humans / students } \\
\text { have the potential so } \\
\text { that students can } \\
\text { solve it by } \\
\text { theirselves. }\end{array}$ \\
\hline 2 & $\begin{array}{l}\text { Guidance should } \\
\text { be focused on } \\
\text { guiding individual. }\end{array}$ & $\begin{array}{l}\text { The differences } \\
\text { among students are a } \\
\text { certainty of the } \\
\text { existence, the teacher } \\
\text { should focus on } \\
\text { students who are } \\
\text { being given guidance } \\
\text { or in other words the } \\
\text { student is unique, } \\
\text { meaning there is no } \\
\text { equal. }\end{array}$ \\
\hline 3 & $\begin{array}{l}\text { Guidance is } \\
\text { directed at the } \\
\text { individual and each } \\
\text { individual has its } \\
\text { own characteristics }\end{array}$ & $\begin{array}{l}\text { The differences in the } \\
\text { characteristics of } \\
\text { students should be } \\
\text { understood } \\
\text { teachers } \\
\text { mathematics, } \\
\text { therefore in the } \\
\text { implementation of } \\
\text { teaching should not } \\
\text { be generalized the } \\
\text { ability of students }\end{array}$ \\
\hline 4 & $\begin{array}{l}\text { Problems that } \\
\text { cannot be resolved } \\
\text { by the coaching } \\
\text { team within the } \\
\text { institutional } \\
\text { environment } \\
\text { should be handed } \\
\text { over to the } \\
\text { authorized expert } \\
\text { or institution }\end{array}$ & $\begin{array}{l}\text { If you find students } \\
\text { who are deemed } \\
\text { incomplete teaching, } \\
\text { the math teacher } \\
\text { coordinates with the } \\
\text { student's parents for } \\
\text { the next step. }\end{array}$ \\
\hline
\end{tabular}

Table 1 (Continued)

Activity Strategy of Teaching Math based on Guidance and Counselling Service Principles

\begin{tabular}{|c|c|c|}
\hline 5 & $\begin{array}{l}\text { Guidance begins } \\
\text { with the } \\
\text { identification of the } \\
\text { perceived needs of } \\
\text { the individual to be } \\
\text { mentored }\end{array}$ & $\begin{array}{l}\text { Teachers in } \\
\text { implementing } \\
\text { teaching strategies } \\
\text { should see or identify } \\
\text { the perceived needs } \\
\text { of students in } \\
\text { learning } \\
\text { mathematics the } \\
\text { completion } \\
\text { keywords. }\end{array}$ \\
\hline 6 & $\begin{array}{lr}\text { Guidance } & \text { should } \\
\text { be } & \text { flexible } \\
\text { according } & \text { to } \\
\text { individual } & \text { and } \\
\text { community needs }\end{array}$ & $\begin{array}{l}\text { Mathematics } \\
\text { teachers' actions } \\
\text { should be flexible in } \\
\text { teaching, frightening } \\
\text { math teachers will be } \\
\text { the concern of } \\
\text { students and the } \\
\text { nuances of teaching } \\
\text { will be unsuccessful. }\end{array}$ \\
\hline 7 & $\begin{array}{l}\text { Guidance programs } \\
\text { in certain } \\
\text { educational } \\
\text { institutions must be } \\
\text { in accordance with } \\
\text { educational } \\
\text { programs at the } \\
\text { institutions } \\
\text { concerned }\end{array}$ & $\begin{array}{ll}\text { Teachers } & \text { of } \\
\text { mathematics } & \text { in } \\
\text { teaching should be } \\
\text { relevant to the } \\
\text { school's mission } \\
\text { vision program and } \\
\text { according } \\
\text { circumstances. }\end{array}$ \\
\hline 8 & $\begin{array}{l}\text { The } \\
\text { implementation of } \\
\text { the guidance } \\
\text { program should be } \\
\text { managed by a } \\
\text { person who has } \\
\text { expertise in the } \\
\text { field of counseling, } \\
\text { can work together } \\
\text { and use relevant } \\
\text { sources within or } \\
\text { outside the } \\
\text { education provider }\end{array}$ & $\begin{array}{l}\text { Mathematics subjects } \\
\text { must have a } \\
\text { mathematical } \\
\text { education discipline. }\end{array}$ \\
\hline 9 & $\begin{array}{l}\text { Guidance program } \\
\text { should be } \\
\text { implemented in } \\
\text { evaluation to know } \\
\text { result and } \\
\text { implementation of } \\
\text { program }\end{array}$ & $\begin{array}{l}\text { In the teaching of the } \\
\text { mathematics teacher } \\
\text { must provide or carry } \\
\text { out evaluation } \\
\text { continuously. }\end{array}$ \\
\hline
\end{tabular}




\section{METHODOLOGY}

This research used survey method to Mathematics Teachers of Junior High School in Kabupaten Karawang by giving questionnaire about teacher's perception of mathematics to understand the application of guidance and counseling service principle in implementation of mathematics teaching strategy. Samples were taken each commissariat of 10 mathematics teachers, so the number of samples were 50 mathematics teachers. The questionnaire was given during MGMP Mathematics at each commissariat.

\section{RESEARCH RESULTS}

The results of questionnaires about teachers' perceptions of mathematics on understanding the application of guidance and counseling service principles in the implementation of mathematics teaching strategies can be considered the following:

1. All math teachers have known about guidance and counseling for a long time when sitting in junior high school to university.

2. Most mathematics teachers never apply the principle of guidance and counseling services when teaching,

3. The wrong perception of mathematics teachers about guidance tasks is that guidance and counseling was only done by guidance and counseling teachers.

4. Most mathematics teachers get the science of counseling guidance in higher education during college.

5. Most mathematics teachers expect counseling and guidance training for subject teachers

\section{E. DISCUSSION}

Based on the results of research, it is required a guidance and counseling movement not only for students, but also it should be expansion to mathematics teachers who have been wrong with the understanding of guidance and counseling through education programs and training guidance and counseling for teachers of mathematics. This is considered reasonable because they know about the science of guidance and counseling only 2 credit hours during the study at the college.

The results of this phenomenon of study should be the basis for submission to related parties, especially the education department of the city so that the proposed procurement of guidance and counseling movement for mathematics teachers can be accepted as an effort to improve the quality of mathematics learning outcomes and change the negative views of students to mathematics over the years.

Indonesian Counseling Guidance Association (ABKIN) as a professional organization of teachers and lecturers of guidance and counseling should immediately respond to the results of this study to participate in providing solutions to improve the quality of learning outcomes and change the negative perception of mathematics and change the mindset of mathematics teachers to counseling guidance.

\section{F. CONCLUSIONS}

Teaching and Learning Strategies in Mathematics is very important to be patterned through the use of guidance and counselling principles from the preparation, implementation and evaluation phase. The preparation phase of the harmonious, happy, and warm of the situation will greatly affect the process of implementation of learning that PAIKEM (active, innovative, creative, effective, and fun learning) will produce qualified students. Sunaryo et al (2008) states that quality education if the three areas implemented synergistically, namely the field of administration, academic and student guidance.

\section{G. REFERENCES}

Departemen Pendidikan Nasional (2004). Panduan Pelaksanaan Bimbingan dan Konseling di Sekolah. Jakarta : Depdiknas

Departemen Pendidikan Nasional, Kurikulum 2004 Standar Kompetensi Mata Pelajaran Matematrika Sekolah Menengah Atas dan MA, Jakarta: Depdiknas,

http://www.academia.edu/11809711/Pengajaran_dan_Pe mbelajaran_Beda_Fokus

M. Djawad Dahlan (2005) Pendidikan dan Konseling di Era Global. Bandung : Rizki

Sunaryo (2008). Kumpulan Artikel Konseling Multi Culter. Bandung : Program Pascasarjana UPI Bandung.

Sutirna (2004). Pembelajaran Matematika bernuansa Bimbingan dan Konseling di SLTP Negeri 2 Karawang. Tesis : tidak diterbitkan

Sutirna (2013). Bimbingan dan Konseling (Formal, Non Formal dan In Formal). Yogyakarta: Andy Ofset

Sutirna (2013). Perkembangan dan Pertumbuhan Peserta Didik. Yogyakarta: Andy Ofset

Syamsu Yusuf LN (1992). Psikologi Kependidikan. Bandung: Andira

The National Council of Teachers Mathematics (in Walle, 2011. 